\title{
Outpatient management of community-acquired pneumonia
}

\author{
Filipe Froes ${ }^{\mathrm{a}}$, João Gonçalves Pereira ${ }^{\mathrm{b}, \mathrm{c}}$, and Pedro Póvoa ${ }^{\mathrm{c}, \mathrm{d}, \mathrm{e}}$
}

\begin{abstract}
Purpose of review
Although most patients with community-acquired pneumonia (CAP) are treated as outpatients, the majority of data regarding CAP management is provided by hospitals, either from emergency department or inpatients. This was already noted in the first CAP guidelines, published in 1993, and the challenges regarding the outpatient management of CAP persist nowadays. These include the uncertainty of the initial diagnosis and risk stratification, the empirical choice of antibiotics, the overgrowing of antibiotic resistance bacteria and the relative scarcity of novel antibiotics.
\end{abstract}

\section{Recent findings}

New molecular biology methods have changed the etiologic perspective of CAP, unveiling the role of virus. Diagnostic uncertainty may lead to antibiotic overuse and bacteria resistance. Novel antibiotics along with diagnostic improvement, related to the use of lung ultrasound and point-of-care biomarkers testing, may help to improve CAP treatment. Prevention, especially the use of antipneumococcal vaccine, is instrumental in reducing the burden of disease.

\section{Summary}

Most of CAP cases are managed in the outpatient setting. However, most research is focused on hospitalized severe patients. New and awaited advances might contribute to aid diagnosis, cause and assessment of patients with CAP in the community. This knowledge might prove decisive in improving outcomes, as well as to the execution of stewardship programs that maintain current antibiotics, safeguard future ones and reinforce prevention.

\section{Keywords}

ambulatory, antibiotic therapy, community-acquired pneumonia, outpatient, pneumonia

\section{INTRODUCTION}

In 2018, the first published international guidelines assessing community-acquired pneumonia (CAP) celebrate its 25 years [1]. This document, published in 1993 by the American Thoracic Society (ATS), was at the same time pioneer and visionary, and deeply changed the management of CAP.

CAP is a frequent entity and its history follows the history of humankind. In 1881, Pasteur [2] and Sternberg [3] independently described a microorganism, named Pneumococcus by Fraenkel because it caused pulmonary disease [4]. Two decades later, William Osler identified the clinical entity of pneumonia as the 'Captain of the men of death' [5]. The introduction of serum therapy, and particularly vaccines and antibiotics, had a major impact in the treatment and prevention of pneumonia during the 20th century. However, in the last 50-60 years, no significant novel treatment has been introduced. Simultaneously new pathogens are increasingly described (e.g. SARS, MERS-CoV) and multidrug-resistant pathogens are a cause of concern. As a result, pneumonia remains a major public health problem, with enormous morbidity and mortality [6].

Despite many advances, some challenges persist since 1993. These include the difficulty in establishing the initial clinical diagnosis, risk stratification, empirical choice of antibiotics, the relative scarcity of novel antibiotics and the importance of knowing

\footnotetext{
antensive Care Unit, Chest Department, Hospital Pulido Valente, Centro Hospitalar Lisboa Norte, Lisbon, ' Intensive Care Unit, Hospital Vila Franca de Xira, Vila Franca de Xira, 'NOVA Medical School, CEDOC, Universidade Nova de Lisboa, ${ }^{\mathrm{d}}$ Polyvalent Intensive Care Unit, Hospital de São Francisco Xavier, Centro Hospitalar de Lisboa Ocidental, Lisbon, Portugal and ${ }^{e}$ Center for Clinical Epidemiology and Research Unit of Clinical Epidemiology, OUH Odense University Hospital, Denmark

Correspondence to Filipe Froes, MD, Unidade de Cuidados Intensivos Médico-Cirúrgicos, Hospital Pulido Valente - CHLN, Alameda das Linhas de Torres, 117, 1769-001 Lisboa, Portugal.

E-mail: filipe.froes@gmail.com
}

Curr Opin Pulm Med 2018, 24:000-000

DOI:10.1097/MCP.0000000000000558 


\section{KEY POINTS}

- The majority of patients with CAP are treated as outpatients, although most of the research on CAP originates from inpatients.

- The main challenges in the outpatient management of CAP persist. These include the initial clinical diagnosis, its risk stratification and the empirical choice of antibiotics.

- Despite the growing acknowledgment of viral agents, all patients with CAP should receive antibiotic treatment. These should be adapted from current guidelines and must take into account local microbiological susceptibility patterns.

- The worrying problem of antibiotic resistance increases the need for stewardship programs along with improvements in diagnostic accuracy, which maintains current antibiotics, safeguards future ones and reinforces prevention.

local microbiological susceptibility patterns. The uncertainty in CAP diagnosis also leads to antibiotic overuse and growing bacteria resistance.

It is expected that the next Infectious Disease Society of America (IDSA)/ATS guidelines actualization due in 2019, will clarify some of these challenges $\left[7^{*}\right]$.

\section{EPIDEMIOLOGY}

Respiratory tract infections (RTI) remain the most common infectious disease in the ambulatory setting [8]. Calculating the true incidence of CAP, however, remains a challenge. Patients with mild systemic and respiratory symptoms rarely seek their general practitioners; this is evident in incidence studies from France with less than seven CAP per year per family physician [9]. The use of confirmatory diagnostic tests varies widely, namely for the availability of chest X-ray and point-of-care testing (POCT). With these limitations, the estimated annual incidence of CAP is 5-11 cases per 1000 adults [10]. CAP incidence presents a marked seasonal variation (more in winter), a U-shaped age distribution (more frequent in children and the elderly), a sex asymmetry (more in men) and is more frequent in the presence of known risk factors (alcohol, tobacco consumption, chronic pulmonary disease, renal failure and malnutrition) or medications (inhaled corticosteroids, proton pump inhibitors, antipsychotic drugs, oral antidiabetic drugs, namely DPP-4 inhibitors) [11",12"].

The percentage of CAP patients admitted to hospital varies from country to country ranging between 1.1 and 4.0 per 1000 inhabitants [13]. This means that roughly two-thirds of patients are treated as outpatients. The annual incidence of hospitalized CAP seems to have decreased slightly in the United States (2.67 to 2.48/1000 inhabitants/year in 2000 and 2010-2012) [14,15], whereas it is increasing in several European countries, such as the UK (1.48-1.98/1000 inhabitants/year between 19971998 and 2004-2005) [13], Germany (2.75-2.96/ 1000 inhabitants/year in 2005 and 2006) [16] and Portugal (3.02-4.70/1000 inhabitants/year in 2000 and 2009) [17]. These differences could reflect different studied populations and healthcare organizations.

A global study found that lower RTI, including pneumonia, ranks fifth as the most common cause of death worldwide, behind Alzheimer disease and other dementias, and shows a slight decrease to $36.8 / 100000$ inhabitants [18]. But even in higher income countries, pneumonia remains the leading cause of death by infectious diseases [ $\left.7^{\boldsymbol{}}\right]$ and ranks eighth amongst the causes of death in the United States in 2014 [19].

The decrease in hospital admissions and CAP mortality observed in some countries $[20,21]$ may be the result of widespread immunization of high-risk groups with pneumococcal and influenza vaccines together with improvement of care process [ $\left.7^{\mathbf{}}\right]$.

\section{CAUSE}

Although more than 100 microorganisms can cause CAP, a limited number account for the majority of cases. Nowadays, the use of molecular diagnostic techniques can yield a microbiological diagnosis in $75 \%$ of cases [22]; however, outside research settings, this figure drops to $10-20 \%$ [23].

In a review of 46 European outpatient studies [24], there was microbiological isolation in half the patients. Pneumococcus was the most common organism accounting for 38\% of isolates. The pneumococcal incidence is higher in countries with lower use of pneumococcal vaccines and higher tobacco use [25]. In Norway, a study of 267 inpatients [26], isolated an aetiological agent in $63 \%$ of cases, mostly pneumococcus (30\%), influenza (15\%) and rhinovirus (12\%). Viral-bacterial co-detections were established in one-third of patients. In another US study, cause was established in 38\% of 2320 patients, particularly rhinovirus (9\%), influenza virus (6\%) and pneumococcus (5\%) [14]. Despite the frequent identification of viruses, their role as colonizers, predisposing to secondary bacterial infection or as microorganisms responsible for pneumonia is not well established, particularly for noninfluenza viruses. 
In the previously mentioned review [24], community-managed CAP was attributed to atypical microorganisms in 30\% of patients. In a study from four Dutch hospitals, atypical microorganisms were isolated in $20.7 \%$ of patients [27]. Risk factors for atypical agents were: noninfluenza season, age less than 60 years, male sex and absence of COPD.

CAP because of Legionella spp. is more frequent in specific geographic locations. Since 2014, several Legionella outbreaks have been reported [28-31]. In the second largest outbreak in the world, with 430 cases, occurred the first documented case of probable person-to-person transmission of Legionnaires' disease [32"].

\section{DIAGNOSIS AND RISK STRATIFICATION}

The definite diagnosis of pneumonia requires systemic manifestations, signs and symptoms of lower RTI, a new or progressive pulmonary infiltrate in chest X-ray and, finally, microbiologic documentation. However, even in severe CAP, microbiologic documentation is obtained in only $50 \%$ of patients.

Radiologic evaluation is rarely available in the primary care setting; hence, family physicians frequently will rely solely on clinical evaluation for CAP diagnosis. Clinical criteria are overly sensitive and poorly specific and, if used indiscriminately, could result in antibiotics overuse.

Older patients, however, often present with atypical symptoms, such as falls, fatigue, lethargy, delirium, anorexia [33]. This is particularly worrying as the elderly are at higher risk of resistant microorganisms and death [34].

Several scoring systems have been developed to stratify severity of pneumonia like the PSI, CURB-65, IDSA/ATS 2007, SMART-COP, SCAP. Although these severity scores performed well in the identification of high-risk patients, they have not been designed to be applied to outpatients. There are three scores that do not require laboratory testing. The NEWS (National Early Warning Score) includes seven items: respiratory rate, peripheral oxygen saturation, oxygen supplementation, temperature, SBP, heart rate and level of consciousness. It has a moderate association with mortality but performed better than PSI and CURB-65 to identify patients needing ICU admission [35]. The other two scores are even simpler and both use the same three clinical items: level of consciousness, respiratory rate and blood pressure. One is an 'old' CAP score, the CRB/ CRB-65 [36,37], the other is a data-driven score using big data, the qSOFA $[38,39]$. The performance of qSOFA for mortality prediction was similar to CRB, but better for ICU admission.
In the near future, POCT will become more available in the primary care setting [40]. Currently, POCT exists for several laboratory variables, such as CRP and PCT, but the array of possibilities is wide and could include microbiologic identification. The challenge is how to use this technology and its additional information. Currently, there are three RCTs performed in primary care settings using a biomarker decision tree algorithm in patients with suspicion of lower RTI [41-43]. In two RCTs, both with less than 500 patients, one using PCT and the other CRP, the authors found a significant decrease in antibiotic prescription without any adverse events. In a Cochrane review published in 2014, $\mathrm{CPR}$ in primary care can reduce antibiotic use; however, with a possible increase in hospitalizations [44]. The larger RCT $(N=1656)$ that evaluated a PCT-guided use of antibiotics for suspected lower RTI, was performed in 14 US hospitals with a high adherence to quality measures. The study showed no impact on the rate of antibiotic prescription and consumption [45"].

The combination of a severity scoring system and a biomarker has also been tested. The additional value of CRP combined with PSI and CURB-65 was evaluated but produced conflicting results $[46,47]$. Probably, more important that any single value of CRP would be its kinetics after $12-24 \mathrm{~h}$, which could contribute to the clinical decision-making process [48]. Other biomarkers, like PCT and proadrenomedulin, have also been tested with similar results $[49,50]$.

Lack of chest imaging in the primary care setting is a major limitation in pneumonia diagnosis. The development of portable ultrasound devices and training of primary care physicians could change the paradigm of pneumonia diagnosis [51].

\section{TREATMENT}

Antibiotic treatment is recommended for all patients with CAP, including outpatients $[1,10,52-56]$. Treatment success relies on prompt delivery of antibiotics, adapted to the likely causative organisms and clinical severity. Antibiotic selection should take into consideration up-to-date local guidelines adapted to the microorganism prevalence and susceptibility pattern (Table 1 ). The antibiotic management of CAP was the subject of a recently published comprehensive review [57"].

Proposed first-line therapy in the outpatient includes monotherapy with a $\beta$-lactam, a macrolide or a tetracycline. These choices exclude those with significant comorbidities or at risk of antibiotic resistance. Fluoroquinolone use is ubiquitous but, from an antibiotic stewardship perspective, a 
Table 1. Guidelines for outpatient treatment of CAP in several countries between 1993 and 2018

\begin{tabular}{|c|c|c|c|c|c|c|}
\hline $\begin{array}{l}\text { Organization } \\
\text { (country) }\end{array}$ & ATS (US) [1] & IDSA/ATS (US) [53] & NICE (UK) [60] & $\begin{array}{l}\text { Chinese Thoracic Society, } \\
\text { Chinese Medical } \\
\text { Association (China) [53] }\end{array}$ & $\begin{array}{l}\text { South African Thoracic Society, } \\
\text { Federation of Infectious Diseases } \\
\text { Societies of Southern Africa [54] }\end{array}$ & $\begin{array}{l}\text { Brazilian Thoracic } \\
\text { Association } \\
\text { (Brazil) [56] }\end{array}$ \\
\hline Year & 1993 & 2007 & 2014 & 2016 & 2017 & 2018 \\
\hline $\begin{array}{l}\text { Outpatient } \\
\text { treatment }\end{array}$ & $\begin{array}{l}60 \text { years or less of } \\
\text { age AND without } \\
\text { comorbidity: } \\
\text { Macrolide } \\
\text { OR } \\
\text { Tetracycline } \\
\text { At least } 60 \text { years of } \\
\text { age AND/OR } \\
\text { comorbidity: } \\
\text { second-generation } \\
\text { cephalosporin } \\
\text { OR } \\
\text { TMP/SMX } \\
\text { OR } \\
\text { Beta-lactam/beta- } \\
\text { lactamase } \\
\text { inhibitor } \\
\pm \\
\text { Macrolide }\end{array}$ & $\begin{array}{l}\text { Previously healthy and } \\
\text { no risk factors for } \\
\text { DRSP infection: } \\
\text { Macrolide } \\
\text { OR } \\
\text { Doxycycline } \\
\text { Presence of } \\
\text { comorbidities (e.g. } \\
\text { chronic heart, lung, } \\
\text { liver, or renal } \\
\text { disease; diabetes } \\
\text { mellitus; alcoholism; } \\
\text { malignancies; } \\
\text { asplenia; } \\
\text { immunosuppressing } \\
\text { conditions or use of } \\
\text { immunosuppressing } \\
\text { drugs); use of } \\
\text { antimicrobials within } \\
\text { the previous } 3 \\
\text { months; or other risks } \\
\text { for DRSP infection: } \\
\text { Fluoroquinolone } \\
\text { OR } \\
\text { ß-lactam and macrolide } \\
\text { (doxycycline is an } \\
\text { alternative to the } \\
\text { macrolide) }\end{array}$ & $\begin{array}{l}\text { Amoxicillin. } \\
\text { Macrolide or } \\
\text { tetracycline for } \\
\text { patients allergic } \\
\text { to penicillin. }\end{array}$ & $\begin{array}{l}\text { Young adults without } \\
\text { underlying disease (s): } \\
\text { Aminopenicillins, penicillins- } \beta \text { - } \\
\text { lactamase inhibitor; } \\
\text { First or second generation } \\
\text { cephalosporins; } \\
\text { Doxycycline or minocycline } \\
\text { (suspected Mycoplasmaor } \\
\text { Chlamydia infection); } \\
\text { fluoroquinolone (in regions } \\
\text { with higher resistance rates } \\
\text { to macrolides or in patients } \\
\text { hypersensitive or intolerant } \\
\text { to the drugs mentioned } \\
\text { above); macrolides (only in } \\
\text { regions with lower } \\
\text { resistance rates). } \\
\text { Patients with underlying } \\
\text { disease(s) or elderly patients } \\
\text { (age >65 years): } \\
\text { Penicillins- } \beta \text {-lactamase inhib.; } \\
\text { Second or third generation } \\
\text { cephalosporin.; } \\
\text { fluoroquinolones; Penicillins- } \\
\beta \text {-lactamase inhibitor or } \\
\text { Second or third generation } \\
\text { cephalosporins plus } \\
\text { doxycycline or minocycline } \\
\text { or macrolides }\end{array}$ & $\begin{array}{l}<65 \text { years old, without antibiotic } \\
\text { exposure in the past } 90 \text { days or } \\
\text { comorbidities: amoxicillin } \\
\text { (macrolide in the presence of } \\
\text { severe } \beta \text {-lactam allergy) } \\
\geq 65 \text { years old, have received } \\
\text { antibiotics within the previous } \\
90 \text { days, or who have } \\
\text { comorbidities: } \\
\text { Amoxicillin-clavulanate OR } \\
\text { second generation cephalosporin }\end{array}$ & $\begin{array}{l}\text { No comorbidities, no } \\
\text { recent use of antibiotics, } \\
\text { no risk factors for } \\
\text { resistance, and no } \\
\text { contraindication or } \\
\text { history of allergy: } \\
\beta \text {-lactam } \\
\text { OR } \\
\text { Macrolide } \\
\text { Use of antimicrobials } \\
\text { within the previous } 3 \\
\text { months, regions where } \\
\text { the rate of resistance to } \\
\text { macrolides is }>25 \% \text {, } \\
\text { concomitant diseases } \\
\text { (COPD, liver or kidney } \\
\text { disease, cancer, } \\
\text { diabetes, congestive } \\
\text { heart failure, alcoholism, } \\
\text { or immunosuppression): } \\
\text { Macrolide combined with } \\
\beta \text {-lactam } \\
\text { OR } \\
\text { Fluoroquinolone }\end{array}$ \\
\hline
\end{tabular}

ATS, American Thoracic Society; COPD, Chronic obstructive pulmonary disease; DRSP, drug-resistant S. pneumoniae; IDSA, Infectious Diseases Society of America; NICE, The National Institute for Health and Care Excellence; TMP/SMX, Trimethoprim/sulfamethoxazole.

\section{Copyright @ 2018 Wolters Kluwer Health, Inc. Unauthorized reproduction of this article is prohibited.}


narrower coverage is preferable, particularly in countries with high tuberculosis prevalence [54].

In a retrospective US analysis from 2011 to 2015, and involving 251947 adult patients, the most commonly prescribed antibiotics to outpatients were macrolides (43.6\%), fluoroquinolones (43\%), $\beta$-lactam compounds (6.5\%) and tetracyclines (5.5\%) [58].

In the United Kingdom [10,59], atypical microorganism coverage is not routinely recommended. However, both Mycoplasma pneumoniae and Chlamydia pneumoniae can cause severe CAP, and adequate antibiotic treatment even in mild disease can reduce morbidity and symptom duration [60].

A recent Dutch study compared monotherapy with a $\beta$-lactam, a fluoroquinolone or a combination of a $\beta$-lactam combined with a macrolide in inpatients [61]. There was no significant difference in 90-day mortality between the three groups. However, this study had several limitations. In $25 \%$ of patients, there was no radiographic confirmation of pneumonia, atypical organisms were identified in only $2 \%$ of patients, $39 \%$ of patients randomized to the monotherapy $\beta$-lactam group had atypical coverage and $12 \%$ of patients to the $\beta$-lactam combined with macrolide did not receive a macrolide $\left[7^{*}, 57^{*}\right]$.

Antimicrobial resistance is a growing problem. The current level of $\beta$-lactam pneumococcal resistance in the community is not generally associated with treatment failure when appropriate agents (e.g. amoxicillin, ceftriaxone, cefotaxime) and adequate doses are used [62]. The incidence of pneumococcal and mycoplasma macrolide resistance reaches 55-
$60 \%$ in China [53] and is now more than 25\% across the whole USA [63], which can limit its use as monotherapy [64]. The use of clinical scores may help identify patients infected with resistant microorganisms [65], and lead to better antibiotic accuracy.

Strategies to reduce the overuse of antibiotics in outpatients, especially for acute RTI (easily mistaken for CAP), are needed, as almost $50 \%$ of these patients receive antibiotics $\left[66^{*}, 67\right]$.

The development of new antibiotics is crucial and new drugs will be available soon. For outpatient management, the most promising seem to be omadacycline and lefamulin (Table 2). Omadacycline is a new, once-daily, intravenous and oral, broadspectrum antibiotic of the tetracycline family that was approved by the Food and Drug Administration (FDA) in October 2018 for the treatment of bacterial CAP. Omadacycline will probably be available in 2019. Also, in 2018, the results of Lefamulin Evaluation Against Pneumonia (LEAP 2) study were presented, showing noninferiority of a 5-day oral lefamulin treatment compared with a standard 7-day oral moxifloxacin treatment [68].

\section{REASSESSMENT}

Effective clinical response to therapy is commonly defined as resolution of fever, normalization of heart and respiratory rate, normal blood pressure and normal oxygen saturation [53]. Among outpatients, treatment failure is usually defined as the need for hospitalization or change in antibiotic therapy.

Table 2. Antibiotics being developed with possible use for outpatient management of community-acquired pneumonia

\begin{tabular}{|c|c|c|c|c|}
\hline Antibiotic & Class & Spectrum of activity & Route & Comments \\
\hline Omadacycline & Tetracycline & $\begin{array}{l}\text { DRSP, atypicals, Staphylococcus } \\
\text { aureus (including MRSA), some } \\
\text { Gram-negatives and bacteria } \\
\text { resistant to older tetracyclines, } \\
\text { like doxycycline }\end{array}$ & $\begin{array}{l}\text { Oral and } \\
\text { intravenous }\end{array}$ & $\begin{array}{l}\text { Approved by the FDA in } \\
\text { October } 2018 \text { for the treatment } \\
\text { of acute bacterial skin and skin } \\
\text { structure infections and community- } \\
\text { acquired bacterial pneumonia }\end{array}$ \\
\hline Lefamulin & Pleuromutilin & $\begin{array}{l}\text { DRSP, atypicals, S. aureus (including } \\
\text { MRSA), some Gram-negatives }\end{array}$ & $\begin{array}{l}\text { Oral and } \\
\text { intravenous }\end{array}$ & $\begin{array}{l}\text { In Lefamulin Evaluation Against } \\
\text { Pneumonia (LEAP 2) study } \\
\text { presented in October 2018, 5-day } \\
\text { oral lefamulin demonstrated } \\
\text { noninferiority for both FDA and } \\
\text { EMA efficacy endpoints versus 7- } \\
\text { day oral moxifloxacin }\end{array}$ \\
\hline Solithromycin & $\begin{array}{l}\text { Ketolide } \\
\text { (fourth } \\
\text { generation } \\
\text { macrolide) }\end{array}$ & $\begin{array}{l}\text { DRSP (including macrolide-resistant), } \\
\text { atypicals (including macrolide- } \\
\text { resistant Mycoplasma } \\
\text { pneumoniae), Moraxella } \\
\text { catarrhalis, S. aureus (including } \\
\text { community-acquired MRSA) }\end{array}$ & $\begin{array}{l}\text { Oral and } \\
\text { intravenous }\end{array}$ & $\begin{array}{l}\text { No developments since December } \\
2016 \text {, after FDA request for further } \\
\text { safety investigations }\end{array}$ \\
\hline
\end{tabular}

DRSP, drug-resistant Streptococcus pneumoniae; EMA, European Medicines Agency; FDA, Food and Drug Administration; MRSA, methicillin-resistant S. aureus. 
Therapeutic failure in outpatients seems to be unusual, ranging from 2.3-8\% [69-71]. Moreover, mortality is low, less than $2.5 \%$ [70], both in patients discharged from the emergency department $[69,72]$ or assessed in the primary care setting. Yet a note of caution is warranted, as mortality in the small group of patients who has late hospital admission may be high [72].

NICE guidelines [59] recommend that lowseverity CAP patients be advised to seek further medical consultation if their symptoms do not begin to improve in a short period of time or if they feel that their condition is deteriorating. This approach seems to be quite intuitive, although there is scarce data to support it. A clinical reevaluation, either in person or by phone, may be a useful approach.

Recommendations should be provided for the ambulatory patient. Treatment failure may also be associated with increased costs. In a large cohort $(N=9446)$ from the United States, authors identified a $58 \%$ increase in costs when treatment failure occurred, with either antibiotic retreatment (89.4\%) or hospitalization (10.6\%) [73].

Follow-up chest X-ray has been recommended, especially for patients at increased risk of underlying neoplastic disease [74]. Delay in the complete resolution of chest infiltrates is common, especially in patients who are aged at least 50 years or with multiple comorbidities [55].

An increase in cardiovascular disease risk after an episode of CAP is increasingly recognized [75"]. It is not known if outpatients with less severe CAP share the same risk.

\section{PREVENTION}

In 2015, the results of the CAPITA trial lead to a significant increase in recommendations for immunization in adults [76]. In the United States, the Advisory Committee on Immunization Practices (ACIP) recommends that all adults aged at least 65 years have the 13-valent pneumococcal conjugate vaccine (PCV13) [77] and at least 1 year later the 23 -valent pneumococcal polysaccharide vaccine (PPSV23) [78]. Yet, the uptake of PCV13 in the United States is low among adults aged 65 and older. Centers for Disease Control and Prevention (CDC) researchers found that by $2016,43 \%$ of beneficiaries had received at least one dose of PPSV23, 32\% one dose of PCV13 and 18\% had received both. The highest vaccination cover was seen among patients who were older, white, or had chronic medical conditions [79]. A review of ACIP recommendations is due on 2019.
In other developed countries, pneumococcal vaccination is widely recommended. France now recommends the scheme PCV13->PPSV23 to all immunocompromised or immunocompetent adults at risk because of a predisposing condition for pneumococcal disease [80]. Both South Africa 2017 and South Korea 2018 CAP guidelines recommend pneumococcal and influenza vaccination as a key pillar of antibiotic stewardship [54,55].

In a real-world study with 2034 CAP inpatients, aged at least 65 years, the PCV13 showed an adjusted effectiveness of $71.1-73.3 \%$ for prevention of CAP caused by the vaccine serotypes [81"]. Several studies $\left[11^{\prime}, 82\right]$ investigated the association between CAP and lifestyle factors. The association lead to a bundle of lifestyle interventions that include responsible alcohol consumption, smoking cessation, dental hygiene, dietary advice to ensure good nutritional status, the avoidance of children with lower RTI and vaccination against influenza and pneumococcus $[82,83]$.

\section{CONCLUSION}

Even though most patients with CAP are treated in the community, the majority of research comes from inpatients. Since the publication of CAP guidelines in 1993 the main challenges persist. These include the difficulty in establishing the initial diagnosis, its risk stratification, the empirical choice of antibiotics and the importance of local microbiological susceptibility patterns. New molecular biology methods have changed the etiologic perspective of CAP, particularly the role of viruses. These methods, along with lung ultrasound and biomarkers might improve diagnosis accuracy and severity stratification. Antibiotic resistance is a growing problem that reinforces the importance of novel antibiotics and disease prevention.

\section{Acknowledgements}

We would like to thank Dr Ana Cysneiros for her assistance with the manuscript.

\section{Financial support and sponsorship}

None.

\section{Conflicts of interest}

F.F. reports personal fees or nonfinancial support from Pfizer, MSD, TEVA, Sanofi, Novartis, Bial, Angelini, outside the submitted work; J.G.P. reports personal fees or nonfinancial support from MSD, Angelini, Pfizer outside the submitted work; P.P. reports personal fees or nonfinancial support from Pfizer, Fresenius Kabi, outside the submitted work. 


\section{REFERENCES AND RECOMMENDED READING}

Papers of particular interest, published within the annual period of review, have been highlighted as:

- of special interest

a. of outstanding interest

1. Niederman MS, Bass JB Jr, Campbell GD, et al. Guidelines for the initial management of adults with community-acquired pneumonia: diagnosis, assessment of severity, and initial antimicrobial therapy. Am Rev Respir Dis 1993; 148:1418-1426.

2. Pasteur $L$. Note on the new disease caused by the saliva of a child who died of rabies. C R Acad Sci 1881; 92:159-165.

3. Sternberg GM. The pneumonia-coccus of Friedlander (Micrococcus Pasteuri. Sternberg). Am J Med Sci 1885; 90:106-123.

4. Fraenkel A. Weitere Beitrage zur Lehre von den Mikrococcen der genuinen fibrinosen Pneumonie [Further contributions to the theory of Micrococci of genuine fibrinous pneumonia]. Zeitschrift filr Klinische Medicin 1886b; 11:437-458.

5. Osler W. The principles and practice of medicine. New York: D. Appleton and Company; 1901.

6. GBD 2013 Mortality and Causes of Death Collaborators. Global, regional, and national age-sex specific all-cause and cause-specific mortality for 240 causes of death 2013 a systematic analysis for the Global Burden of Disease Study 2013. Lancet 2015; 385:117-171.

7. Wunderink RG, Waterer G. Advances in the causes and management of

- community acquired pneumonia in adults. BMJ 2017; 358:j2471.

IDSA/ATS guidelines update anticipated in 2017.

8. Zweigner J, Meyer E, Gastmeier P, Schwab F. Rate of antibiotic prescriptions in German outpatient care - are the guidelines followed or are they still exceeded? GMS Hyg Infect Control 2018; 13:; Doc04.

9. Société Française de Médecine Générale. Observatoire de la Médecine Général. Données en consultation pour: Pneumophatie Aigue. Available at: http://omg.sfmg.org/content/donnees/donnees.php. (Accessed 28 October 2018).

10. Lim WS, Baudouin SV, George RC, et al., Pneumonia Guidelines Committee of the BTS Standards of Care Committee. BTS guidelines for the management of community acquired pneumonia in adults: update 2009. Thorax 2009; 64(Suppl 3); iii1-55.

11. Almirall J, Serra-Prat M, Bolíbar I, Balasso V. Risk factors for community-

- acquired pneumonia in adults: a systematic review of observational studies. Respiration 2017; 94:299-311.

Comprehensive review of risk factors for CAP

12. Liapikou $A$, Cilloniz $C$, Torres $A$. Drugs that increase the risk of community-

- acquired pneumonia: a narrative review. Expert Opin Drug Saf 2018; 17:991-1003

Comprehensive review of drugs that increase the risk of CAP.

13. Trotter CL, Stuart JM, George R, Miller E. Increasing hospital admissions for pneumonia, England. Emerg Infect Dis 2008; 14:727-733.

14. Jain S, Self WH, Wunderink RG, et al., CDC EPIC Study Team. CommunityAcquired pneumonia requiring hospitalization among U.S. adults. $\mathrm{N}$ Engl J Med 2015; 373:415-427.

15. Marston BJ, Plouffe JF, File TM Jr, et al. Incidence of community-acquired pneumonia requiring hospitalization. Results of a population-based active surveillance Study in Ohio. The Community-Based Pneumonia Incidence Study Group. Arch Intern Med 1997; 157:1709-1718.

16. Ewig S, Birkner N, Strauss R, et al. New perspectives on community-acquired pneumonia in 388406 patients. Results from a nationwide mandatory performance measurement programme in healthcare quality. Thorax 2009; 64:1062-1069.

17. Froes F, Diniz A, Mesquita M, et al. Hospital admissions of adults with community-acquired pneumonia in Portugal between 2000 and 2009. Eur Respir J 2013; 41:1141-1146.

18. GBD 2016 Causes of Death Collaborators. Global, regional, and national age-sex specific mortality for 264 causes of death, 1980-2016: a systematic analysis for the Global Burden of Disease Study 2016. Lancet 2017; 390:1151-1210.

19. Kenneth D, Kochanek MA, Sherry L, et al. Deaths: final data for 2014. Natl Vital Stat Rep 2016; 65:1-122.

20. Rhee C, Gohil S, Klompas M. Regulatory mandates for sepsis care-reasons for caution. N Engl J Med 2014; 370:1673-1676.

21. Stevenson EK, Rubenstein AR, Radin GT, et al. Two decades of mortality trends among patients with severe sepsis: a comparative meta-analysis. Crit Care Med 2014; 42:625-631.

22. Lim WS, Macfarlane JT, Boswell TCJ, et al. Study of community acquired pneumonia aetiology (SCAPA) in adults admitted to hospital: implications for management guidelines. Thorax 2001; 56:296-301.

23. Durrington HJ, Summers C. Recent changes in the management of community acquired pneumonia in adults. BMJ 2008; 336:1429-1433.

24. Welte T, Torres A, Nathwani D. Clinical and economic burden of communityacquired pneumonia among adults in Europe. Thorax 2012; 67:71-79.
25. Musher DM, Thorner AR. Community-acquired pneumonia. N Engl J Med 2014; 371:1619-1628.

26. Holter JC, Müller F, Bjørang $\mathrm{O}$, et al. Etiology of community-acquired pneumonia and diagnostic yields of microbiological methods: a 3-year prospective study in Norway. BMC Infect Dis 2015; 15:64.

27. Raeven VM, Spoorenberg SM, Boersma WG, et al., Alkmaar study group; Ovidius study group. Atypical aetiology in patients hospitalised with community-acquired pneumonia is associated with age, gender and season; a data analysis on four Dutch cohorts. BMC Infect Dis 2016; 16:299.

28. Weiss D, Boyd C, Rakeman JL, et al., South Bronx Legionnaires' Disease Investigation Team. A large community outbreak of legionnaires' disease associated with a cooling tower in New York City, 2015. Public Health Rep 2017; 132:241-250.

29. Thornley CN, Harte DJ, Weir RP, et al. Legionella longbeachae detected in an industrial cooling tower linked to a legionellosis outbreak, New Zealand, 2015; possible waterborne transmission? Epidemiol Infect 2017; 145: 2382-2389

30. Kuroki T, Amemura-Maekawa J, Ohya H, et al. Outbreak of Legionnaire's disease caused by Legionella pneumophila Serogroups 1 and 13. Emerg Infect Dis 2017; 23:349-351.

31. George F, Shivajia T, Sousa Pinto C, et al. A large outbreak of Legionnaires' disease in an industrial town in Portugal. Rev Port Saúde Pública 2016; 34:199-208.

32. Correia AM, Gonçalves J, Gomes J, et al. Probable person-to-person trans-

- mission of Legionnaires' disease. N Engl J Med 2016; 374:497-498.

This article questions the route of transmission in Legionnaire's disease with epidemiological implications.

33. Cillóniz C, Rodríguez-Hurtado D, Torres A. Characteristics and management of community-acquired pneumonia in the era of global aging. Med Sci (Basel) 2018; 6:; pii: E35.

34. Hamaguchi S, Suzuki M, Sasaki K, et al. Six underlying health conditions strongly influence mortality based on pneumonia severity in an ageing population of Japan: a prospective cohort study. BMC Pulm Med 2018; 18:88.

35. Sbiti-Rohr D, Kutz A, Christ-Crain M, et al., ProHOSP Study Group. The National Early Warning Score (NEWS) for outcome prediction in emergency department patients with community-acquired pneumonia: results from a 6year prospective cohort study. BMJ Open 2016; 6:e011021.

36. Lim WS, van der Eerden MM, Laing R, et al. Defining community acquired pneumonia severity on presentation to hospital: an international derivation and validation study. Thorax 2003; 58:377-382.

37. Bauer TT, Ewig S, Marre R, et al., CAPNETZ Study Group. CRB-65 predicts death from community-acquired pneumonia. J Intern Med 2006; 260: 93-101.

38. Ranzani OT, Prina E, Menéndez R, et al. New sepsis definition (sepsis-3) and community-acquired pneumonia mortality. a validation and clinical decisionmaking study. Am J Respir Crit Care Med 2017; 196:1287-1297.

39. Kolditz M, Scherag A, Rohde G, et al., CAPNETZ Study Group. Comparison of the qSOFA and CRB-65 for risk prediction in patients with communityacquired pneumonia. Intensive Care Med 2016; 42:2108-2110.

40. Gal M, Francis NA, Hood K, et al., RAPP-ID Consortium. Matching diagnostics development to clinical need: Target product profile development for a point of care test for community-acquired lower respiratory tract infection. PLoS One 2018; 13:e0200531.

41. Briel $M$, Schuetz $P$, Mueller $B$, et al. Procalcitonin-guided antibiotic use vs a standard approach for acute respiratory tract infections in primary care. Arch Intern Med 2008; 168:2000-2007.

42. Cals JW, Hopstaken RM, Butler CC, et al. Improving management of patients with acute cough by $\mathrm{C}$-reactive protein point of care testing and communication training (IMPAC3T): study protocol of a cluster randomised controlled trial. BMC Fam Pract 2007; 8:15.

43. Cals JW, Butler CC, Hopstaken RM, et al. Effect of point of care testing for $\mathrm{C}$ reactive protein and training in communication skills on antibiotic use in lower respiratory tract infections: cluster randomised trial. BMJ 2009; 338:b1374.

44. Aabenhus $\mathrm{R}$, Jensen JUS, Jørgensen $\mathrm{KJ}$, et al. Biomarkers as point-of-care tests to guide prescription of antibiotics in patients with acute respiratory infections in primary care. Cochrane Database Syst Rev 2014; CD010130.

45. Huang DT, Yealy DM, Filbin MR, et al. Procalcitonin-guided use of antibiotics

- for lower respiratory tract infection. N Engl J Med 2018; 379:236-249.

In hospitals with high compliance to quality measure practices, PCT did not prove useful in guiding antibiotic prescription.

46. Menéndez R, Martínez R, Reyes $\mathrm{S}$, et al. Biomarkers improve mortality prediction by prognostic scales in community-acquired pneumonia. Thorax 2009; 64:587-591.

47. Yamamoto $S$, Yamazaki S, Shimizu T, et al. Prognostic utility of serum CRP levels in combination with CURB-65 in patients with clinically suspected sepsis: a decision curve analysis. BMJ Open 2015; 5:e007049.

48. Póvoa $P$, Coelho $L$, Almeida $E$, et al. Early identification of intensive care unitacquired infections with daily monitoring of $\mathrm{C}$-reactive protein: a prospective observational study. Crit Care 2006; 10:R63.

49. Kim MW, Lim JY, Oh SH. Mortality prediction using serum biomarkers and various clinical risk scales in community-acquired pneumonia. Scand J Clin Lab Invest 2017; 77:486-492. 
50. Liu $\mathrm{D}, \mathrm{Xie} \mathrm{L}$, Zhao $\mathrm{H}$, et al. Prognostic value of mid-regional pro-adrenomedullin (MR-proADM) in patients with community-acquired pneumonia: a systematic review and meta-analysis. BMC Infect Dis 2016; 16:232.

51. Chavez MA, Shams N, Ellington LE, et al. Lung ultrasound for the diagnosis of pneumonia in adults: a systematic review and meta-analysis. Respir Res 2014; 15:50.

52. Mandell LA, Wunderink RG, Anzueto A, et al., Infectious Diseases Society of America; American Thoracic Society. Infectious Diseases Society of America/ American Thoracic Society consensus guidelines on the management of community-acquired pneumonia in adults. Clin Infect Dis 2007; 44(Suppl 2):S27-S72.

53. Cao B, Huang $Y$, She DY, et al. Diagnosis and treatment of communityacquired pneumonia in adults: 2016 clinical practice guidelines by the Chinese Thoracic Society, Chinese Medical Association. Clin Respir J 2018; $12: 1320-1360$

54. Boyles TH, Brink A, Calligaro GL, et al. South African Thoracic Society; Federation of Infectious Diseases Societies of Southern Africa. South African guideline for the management of community-acquired pneumonia in adults. J Thorac Dis 2017; 9:1469-1502.

55. Lee MS, Oh JY, Kang C, et al. Guideline for antibiotic use in adults with community-acquired pneumonia. Infect Chemother 2018; 50:160-198.

56. Corrêa RA, Costa NA, Lundgren F, et al. 2018 recommendations for the management of community acquired pneumonia. J Brasil Pneumol 2018; 44:405.

57. Bender MT, Niederman MS. Principles of antibiotic management of commu- nity-acquired pneumonia. Semin Respir Crit Care Med 2016; 37:905-912. Comprehensive review of antibiotic management in CAP including the immunomodulator effect of macrolides.

58. Landsman-Blumberg $P$, Carroll $C$, Murty $S$, et al. Meeting Abstracts - Academy of Managed Care Pharmacy Nexus 2016. Antibiotic treatment failure in adults with community-acquired bacterial pneumonia: an analysis of a large U.S. Claims Database. J Managed Care Specialty Pharmacy 2016; 22:J05.

59. NICE. National Institute for Health and Care Excellence. Clinical Guideline [CG191]. Pneumonia in adults: diagnosis and management. Published: 3 December 2014. nice.org.uk/guidance/cg191.

60. File TM, Garau J, Blasi F, et al. Guidelines for empiric antimicrobial prescribing in community-acquired pneumonia. Chest 2004; 125:1888-1901.

61. Postma DF, vanWerkhoven $\mathrm{CH}$, van Elden $\mathrm{LJ}$, et al., CAP-START Study Group. Antibiotic treatment strategies for community-acquired pneumonia in adults. N Engl J Med 2015; 372:1312-1323.

62. File TM. Treatment of community-acquired pneumonia in adults in the outpatient setting. UpToDate. www.uptodate.com. (Accessed 22 November 2018)

63. Haran JP, Volturo GA. Macrolide resistance in cases of community-acquired bacterial pneumonia in the emergency department. J Emerg Med 2018; 55:347-353.

64. Mandell LA. Something new for community-acquired pneumonia? Clin Infect Dis 2016; 63:1681-1682.

65. Kobayashi $D$, Shindo $Y$, Ito $R$, et al. Validation of the prediction rules identifying drug-resistant pathogens in community-onset pneumonia. Infect Drug Resist $2018 ; 11: 1703-1713$

66. Silverman M, Povitz M, Sontrop JM, et al. Antibiotic prescribing for nonbac-

- terial acute upper respiratory infections in elderly persons. Ann Intern Med $2017 ; 166: 765-774$.

Mid-career or late-career physicians with high patient volumes were more likely to prescribe antibiotics.

67. McDonagh MS, Peterson $\mathrm{K}$, Winthrop $\mathrm{K}$, et al. Interventions to reduce inappropriate prescribing of antibiotics for acute respiratory tract infections: summary and update of a systematic review. J Int Med Res 2018; 46: $3337-3357$
68. Alexander E, Goldberg L, Das A, et al. LB6 - Oral lefamulin is safe and effective in the treatment of adults with community-acquired bacterial pneumonia (CABP):- Results of Lefamulin Evaluation Against Pneumonia (LEAP 2) Study. IDWeek 2018. Abstract Session: Late Breaker Oral Abstracts: HIV and Antibiotic Trials. Available at: https://idsa.confex.com/idsa/2018/webprogram/Paper74297.html.

69. Cillóniz C, Ewig S, Polverino E, et al. Community-acquired pneumonia in outpatients: aetiology and outcomes. Eur Respir J 2012; 40:931-938.

70. Fantin $B$, Aubert JP, Unger $P$, et al. Clinical evaluation of the management of community-acquired pneumonia by general practitioners in France. Chest 2001; 120:185-192.

71. Minogue MF, Coley CM, Fine MJ, et al. Patients hospitalized after initial outpatient treatment for community-acquired pneumonia. Ann Emerg Med 1998; 31:376-380.

72. Pavié GJ, de la Prida CJM, Díaz FA, Saldías PF. Manejo de la neumonía comunitaria del adulto en el Servicio de Salud Viña del Mar-Quillota. Abril Septiembre de 2003. Rev Chil Enfermedades Respir 2006; 22:7-12.

73. Asche C, McAdam-Marx C, Seal B, et al. Treatment costs associated with community-acquired pneumonia by community level of antimicrobial resistance. J Antimicrob Chemother 2008; 61:1162-1168.

74. Holmberg $\mathrm{H} 1$, Kragsbjerg $P$. Association of pneumonia and lung cancer: the value of convalescent chest radiography and follow-up. Scand J Infect Dis 1993; 25:93-100.

75. Restrepo MI, Reyes LF. Pneumonia as a cardiovascular disease. Respirology

2018; 23:250-259.

Comprehensive review of the risk factors and cardiovascular damage affecting patients with CAP.

76. Bonten MJ, Huijts SM, Bolkenbaas M, et al. Polysaccharide conjugate vaccine against pneumococcal pneumonia in adults. N Engl J Med 2015; 372: 1114-1125.

77. Tomczyk S, Bennett NM, Stoecker C, et al., Centers for Disease Control and Prevention (CDC). Use of 13-valent pneumococcal conjugate vaccine and 23 -valent pneumococcal polysaccharide vaccine among adults aged $\geq 65$ years: recommendations of the Advisory Committee on Immunization Practices (ACIP). MMWR Morb Mortal Wkly Rep 2014; 63:822-825.

78. Kobayashi M, Bennett NM, Gierke R, et al. Intervals between PCV13 and PPSV23 vaccines: recommendations of the Advisory Committee on Immunization Practices (ACIP). MMWR Morb Mortal Wkly Rep 2015; 64: 944-947.

79. Black CL, Williams WW, Warnock R, et al. Pneumococcal vaccination among medicare beneficiaries occurring after the Advisory Committee on Immunization Practices Recommendation for routine use of 13-valent pneumococcal conjugate vaccine and 23-valent pneumococcal polysaccharide vaccine for adults aged $\geq 65$ years. MMWR Morb Mortal Wkly Rep 2017; 66: $728-733$

80. Ministère des Affaires Sociales et de la santé - République Française. Calendrier des vaccinations et recommandations vaccinales 2017. 2.11 Infections à pneumocoque (ip). Available at: http://solidarites-sante.gouv.fr/ IMG/pdf/calendrier vaccinations 2017.pdf.

81. McLaughlin JM, Jiang $Q$, Isturiz RE, et al. Effectiveness of 13-valent pneu-

- mococcal conjugate vaccine against hospitalization for community-acquired pneumonia in older US adults: a test-negative design. Clin Infect Dis 2018; $67: 1498-1506$

The first study in real-world conditions to demonstrate a superior effectiveness of PCV13 in adults aged at least 65 years compared with CAPITA Study.

82. Torres A, Peetermans WE, Viegi G, Blasi F. Risk factors for communityacquired pneumonia in adults in Europe: a literature review. Thorax 2013; 68:1057-1065

83. Froes F, Blasi F, Torres A. Achoo, achis, ATCHIN! Vaccine you. ... Eur Respir J 2018; 51:1702558. 